FROM THE EDITOR

Barry Trott

\section{Connie Van Fleet, an Appreciation}

Correspondence for Reference \& User Services Quarterly should be addressed to Editor Barry Trott, Williamsburg Regional Library, 7770 Croaker Rd., Williamsburg, VA, 23188; email: btrott@wrl.org.
Connie Van Fleet, who died on February 5, 2013, served as coeditor of this journal with her husband Danny Wallace for twelve years, longer than any other editors. Their work maintained the journal's "status as a premier publication for academic and public librarians engaged in reference and user services." Connie's skill as an editor, writer, teacher, and mentor will be missed by many in the library profession. I was fortunate enough to have the chance to work with Connie in several of those roles. She and Danny offered me the opportunity to edit the readers' advisory column in RUSQ and were patient instructors in the ways of academic publishing. Their willingness to give new writers a voice started me on the path to becoming current editor of the journal and shaped my view of the role of editor. I also had the pleasure to have Connie write a column for me on readers' advisory education in LIS programs. Moving from the role of editor to the one being edited can be challenging, but Connie was a delight to work with as a writer, open to ideas and accepting suggestions with grace. I learned a great deal simply from watching how Connie went about her work, with passion, with thoughtfulness, and always with joy. That is a model we all should all aspire to in our practice. In this column, I have asked some of Connie's teachers, colleagues, and former students to share their memories of Connie.—Editor

Connie Van Fleet submitted an application to the Louisiana State University, School of Library and Information Science master's program in 1985. When I read her statement of purpose I simply picked up the phone, called her at the Napoleon branch of the New Orleans Public Library and asked her to come to LSU to study full-time right away. The field of public librarianship needed this young woman's passion and intellect.

At that time I had an ALA Goal Award grant for the project "Adult Services in the Eighties Project" to replicate the 1952-1953 Helen Lyman Smith study. Connie Van Fleet was appointed Project Coordinator 1986-1987. In addition to the coordination work, she reported on the project for the ALA Yearbook of Library and Information Services, for $R Q$, and for the Literacy Alert Newsletter of the Louisiana Library Association. She did all this while a mother, a full-time master's student, and president of the Graduate Library and Information Science Students Association.

Connie displayed such a keen intelligence and deep concern for lifelong learning that she went right from the LSU program to doctoral work. As a doctoral student at Indiana University she continued scholarship on adult services, writing two substantive essays: "Lifelong Learning Theory and 
the Provision of Adult Services" and "The Public Library as a Social/Cultural Institution: Alternative Perspectives and Changing Contexts," which appeared in Adult Services: An Enduring Focus for Public Libraries (American Library Association, 1990). These are both classic scholarly assessments and are regularly used in LIS programs world-wide.

Others writing tributes here will address Connie's career on different pathways, but I think the honor bestowed upon her in 1996, the Margaret E. Monroe Library Adult Services Award by the Reference and Adult Services Division "Honoring a librarian who has made a distinguished contribution to and an impact on library adult services," stands out as the shining example of the full circle of her career-from librarian in an urban setting working with a diverse clientele, to distilling and analyzing lifelong learning needs to extend her perceptions to students and librarians serving adults.

But most of all, I remember Connie and other LSU graduate students from the Research Annex standing on the steps of the state capitol in Baton Rouge waving signs, to "Save Our Libraries." Connie worked her whole life to save libraries so that all may learn.-Kathleen de la Peña McCook

I had the pleasure of helping to organize a reception in honor of Connie Van Fleet and Danny Wallace at the 2006 ALA Annual Conference in New Orleans. The occasion was to mark the end of their service as coeditors of Reference \& User Services Quarterly. It was the perfect venue since New Orleans is a city that meant a great deal to Connie. The ballroom was full of people who loved them, including members of Connie's family. Connie and Danny had achieved a number of editorial firsts. They had the distinction of editing the journal for the greatest number of years (twelve in total). They were the journal's first joint (as well as husband-wife) editorial team. Their eloquent, witty, and smart editorials were their trademarks. Connie in particular had a way of making editing look effortless. She was a warm and supportive mentor to me when I assumed the editorship of the journal. The most important lesson that I learned from her was kindness, especially the importance of treating all prospective authors with respect.—Diane Zabel

When I mentioned that my husband and I were about to take our first trip to New Orleans, Connie leapt merrily into Zagat mode, giving me very specific instructions about what to order at Mother's (for lunch, she stressed, not dinner) and earnest warnings about hurricane cocktails for the uninitiated (just because they taste like candy doesn't mean they won't knock you over, an important life lesson). So, since it was her idea that we should cap our trip with breakfast at Brennan's, it wasn't really a huge surprise to glance up from the Bananas Foster and see the hostess seating Connie and Danny and their guests a few tables over. We visited for a minute, exchanging introductions and chuckles and the obligatory "small world" comments before going on our way. It's not a profound moment-it's not even a remarkable coincidence. But the reason I love that story is that as we left, I overheard
Connie's sister say, "You don't even live in this city, and still we run into your friends all the time." And that, to me, is Connie. Her friendship was so precious, and yet she wasn't at all stingy with it. She had a remarkable ability to draw people to her, to create sincere connections, and to make everyone who had the privilege of knowing her feel valued. Of course they met her friends everywhere they went. She made them everywhere.-Molly Strothmann

When Connie Van Fleet entered the MLIS Program at Louisiana State University in 1985, I was the Library and Information Science Librarian. I was also engaged in my own diversity work with SLIS students. It was when Connie returned from Indiana University upon receipt of her doctorate and joined the SLIS faculty that we connected over the issue of diversity — a passion dear to both our hearts. In 1990, Dr. Van Fleet and I organized the Minority Recruitment and Professional Concerns Interest Group (renamed the Diversity Interest Group in 2003) within the Louisiana Library Association (LLA) as a partnership between the LLA and LSU School of Library and Information Science, to facilitate minority recruitment and to support professional activity among minority librarians. Through this network (which continues today) minority students were recruited, educated, and graduated. Minority professionals were involved in professional development activities at conferences and in the mentoring program of the LSU School of Library and Information Science. ${ }^{2}$ African American Literature: A Guide to Reading Interests, which Connie and I coedited, reflects Connie's interest in the literature of diversity, particularly African American Literature. This volume was unique in that it was the first to address the subject. Other works would include book chapters on African American authors and multicultural literature, some of which I coauthored. Connie's career reflects a continuing interest on the subject of diversity. Connie's life work in diversity is reflected in both her professional service and scholarship. I will miss my friend and supporter.—Alma Dawson

My memories of Connie Van Fleet are of a brilliant and caring colleague who was ever willing to listen and give insightful feedback. We shared good times with laughter and spontaneous hugs and also times of difficulty, when she would furrow her brow, look me in the eye, lean in, and fully reveal her generous spirit and optimistic outlook. It was fun to be with Connie. We worked together on many occasions, including when I was RUSA representative to the RUSQ editorial board and on several ALISE committees and events. One memory to share was when we both ran for ALISE president for 2006-2007. We were approached separately to run and were absolutely aghast when we found out we would be on the ballot as opponents in the election. I picked up the phone immediately when I found out, and Connie said, "I was just about to call you, this is just WRONG." We both started laughing and we talked about which one of us should withdraw because we both thought the other one should be president and run unopposed. In the end, we decided to both run anyway, for the 


\section{FROM THE EDITOR}

good of ALISE. Connie won by a slim majority (so I was told, but maybe this was so my ego would not be so badly bruised). During the next ALISE conference, right after her election announcement, I ran into Connie and her publisher, Ron Maas from Libraries Unlimited, in the hotel lounge. It looked to me like they were drinking champagne. So I mischievously said "Oh, what are you celebrating?" She said sheepishly "my election" and then, with her megawatt smile, "come and join us!" and I did. Great times together, no hard feelings, what a loss, I really miss her.-Marie L. Radford

Connie Van Fleet was a dear friend and colleague. Her compassion for others made Connie such a wonderful teacher, friend, and colleague. She always knew what to say to reassure and give advice without anyone ever realizing what she actually was doing. Connie would talk to me about my challenges and difficult situations in a way that guided me to some type of resolution. In this way, she was a true leader. She always was a calming force who would tackle most challenges with a sense of humor.

Connie also had a way of connecting people who were compatible in some way. She told me that she wanted to introduce me to one of her very dear friends, October Ivins, because we had so much in common and would get along well. When Connie did connect us, she was right on, and she has given us both the gift of a new and wonderful friendship that will continue to develop and grow.

I worked very closely with Connie when she was the vicepresident/president elect and president of the Association for Library and Information Science Education (ALISE). She led the development of the structural support systems and procedures for the association, which I greatly value as an ongoing chair of an ALISE Committee. Connie worked very hard to move the association into a new era. Connie Van Fleet was a great leader, who always took the humanistic approach, and I feel privileged to have had the opportunity to include her in my life. I will miss Connie's enthusiasm and smile and especially her friendship._Lynn Silipigni Connaway

While most celebrating the life of Connie Van Fleet know her from her ALA work and scholarship, I had the privilege of first getting to know Connie during my time as a library school student at Louisiana State University in 1989. I believe I was part of the first class Connie taught, a wrap up class that one took in one's last semester. She was finishing her PhD and serving as an instructor at LSU. The library school was very friendly, with the faculty inviting us into their homes for parties. However, the faculty was addressed by the surnames preceded by Doctor. Connie was different. She walked into class and said with a big smile, "Call me Connie." It was not just that Connie was still completing her dissertation, it was that she treated everyone as her equal. We spent the semester discussing the big issues facing librarians, but what I recall most is her constant smile and laughter. She made the class fun. After graduating, I got to know Connie better through ALA committee work. It was always a pleasure running into her at conferences. Her smile and laughter continued each time she would see me or one of her former students. She always treated everyone with the utmost respect, and her interest and care always remained strong. I will miss Connie's smile and laughter, and now that I have started teaching as an adjunct, I plan to emulate her friendly demeanor in her honor.-Bobray Bordelon

Who knew editing a library journal could be such fun? Certainly not me before I came on board as a graduate student assistant to RUSQ editors Connie van Fleet and Danny Wallace in January 2003, during my first semester in the School of Information and Library Studies program at the University of Oklahoma. I have fond memories of weekly meetings where the serious business of processing and critiquing submissions was noticeably lightened through Connie's infectious laughter, sharp wit, and whimsical take on this or that topic. But of course the experience was more than just fun. Working with the editors during their final years at the helm of RUSQ was an incredible educational experience and professional opportunity. In retrospect, I can't imagine a more perfect introduction to librarianship.

It was through the experience of seeing Connie at work as an editor that I first gained a sense of her amazing network of entwined professional and personal relationships. This spoke volumes about her influence in the field and her standing as a scholar, colleague, and teacher. I marvel at all the qualities and talents that made Connie special but want to highlight one that touches so many of us-her gifts as a mentor. In this role, Connie displayed a seeming endless capacity to advocate for her students and to work actively on behalf of their ongoing professional success.

I had the privilege of being mentored by Connie. I benefited tremendously from the wise counsel and advice she provided in her roles as supervisor, instructor, and thesis advisor. Connie introduced me to the wonderful world of readers' advisory; her enthusiasm and excitement for the possibilities for research and practice in this area were truly inspiring and left a lasting imprint. She guided me to creative ways of integrating my interests in history of science and popular culture with this area of librarianship. She continues to be an inspiration for me on so many levels and in so many invaluable ways, both professional and personal.

Connie is an irreplaceable friend and mentor. I will miss so many things about her but especially her laughter and her joyful, loving, generous spirit.—JoAnn Palmeri

I cannot yet imagine a world without Connie Van Fleet. I first knew Connie when she was a student in the MLIS program at LSU. Her work was always the best in the class: her participation in discussions was a little better focused and her writing was a little more polished. She managed to squeeze more into a day and to accomplish more than most students, and she made sure everyone was having fun. After she earned her $\mathrm{PhD}$, Connie returned to LSU to be my colleague, and with her ever present enthusiasm she continued to accomplish 
more than most of us. We often laughed after putting in long days and late nights in order to meet a deadline, saying "If only I had three more hours." Connie, today I wish we had three more hours.-Beth Paskoff

In 2001, I was in library school at the University of Oklahoma. I was taking the reference class from Dr. Van Fleet, as I called her when she was my professor and advisor, and also working for her and Danny Wallace as an editorial assistant for RUSQ. Naturally, I idolized Connie and hoped to be just like her when I "grew up." One of my most vivid memories of Connie comes from that year. I remember standing around in the old wing of the library talking with her about something or another, and she suddenly remarked, "I can't wait until you graduate so we can really be friends!"

This made me feel remarkably special, of course (so much so that I remember it quite clearly a dozen years later), and in due course, I graduated and our relationship did evolve from the prescribed student-teacher roles into friendship. I began calling her "Connie" instead of "Dr. Van Fleet." All of this was special. Yet when I think about it in retrospect, perhaps I shouldn't have felt all that special because Connie developed real friendships, real connections, with dozens or hundreds of students over the years. I was just one of Connie's very many students-turned-colleagues-turned-friends.

But Connie's friendship had some magical quality—even though she spread it around among hundreds of people, it never felt diluted. When I was spending time with her, I felt like the most important person in her orbit.-Karen E. Antell

Connie Van Fleet was my advisor and professor while I was in library school at LSU. She continued to advise me even after she left Louisiana for Kent State, and later the University of Oklahoma. Beyond that, she was my mentor and friend, and we tried to stay in touch, getting together at conferences whenever we could.

I am writing this from the Louisiana Library Association Conference, and Connie's presence is everywhere. I attended a meeting of the Diversity Interest Group, which Connie and Alma Dawson founded back in the 1990s in recognition of the need for more diversity in our profession. I saw a friend that I first met in the readers' advisory class we took with Connie so many years ago. Readers' advisory was not a part of the curriculum at that time but Connie felt it was an important part of what we do in public libraries so she developed it as a special topics course; it later became, and continues to be, part of the LSU SLIS curriculum. I talked with a another friend about the importance of being involved in professional activities as well as the importance of being able to occasionally say no-things Connie taught me. As I stood in the exhibit hall looking around at all my colleagues, I thought of her outreach efforts beyond the classroom to the small and rural libraries all around the state, thought of all the lives she touched.

I believe that through the things she taught me, both in and out of the classroom, the encouragement and advice she gave, the people she introduced me to, and the laughter we shared, Connie Van Fleet helped me to become the librarian I am today. I doubt I am the only one._Vicki Nesting

To say she was brilliant, talented, accomplished, kind, funloving, and beautiful somehow doesn't say it all about Connie. I first met her in the 1990s, and I worked with her as her editor and professional colleague since then. We published three books together, along with her coeditors and coauthor (Case Study Evaluation, African American Literature, and most recently, Knowledge into Action: Research and Evaluation in Library and Information Science); she also contributed to the sixth edition of Genreflecting. Connie always made our work fun - whether it was planning and editing a book, or working as an advisor on our online database, Reader's Advisor Online. This was not just because she knew her subjects thoroughly, had great ideas, and was an elegant writer or because she was a terrifically hard worker. It was more than that. She always brought her full presence to every project, and working became not a singularly-focused act of duty or drudgery-it was a way to share the joys and insights of her own experiences and expertise. She peppered her conversations with colorful stories about growing up in New Orleans, something she was very proud of, providing historical anecdotes about her family or her career path or discussing the state of profession. We had many serious discussions over dinner, often with her husband Danny, who also provided provocative discernments, which I literally had to pull myself away from.

I will miss Connie. She deeply loved and respected her family and was more than an author or associate to me. Fiercely loyal to libraries and librarians-and particularly devoted to public libraries_-she was a friend to us all. -Barbara Ittner

\section{References}

1. Diane Zabel, "A Hard Act to Follow," RUSQ 46, no. 1 (2006): 4.

2. Alma Dawson, "Recruitment of Diverse Populations to Librarianship: Documenting the Partnership between the LSU School of Library and Information Science and the LLA Minority Recruitment and Professional Concerns Interest Group," Louisiana Libraries 63, no. 3 (2001): 5-13. 